\title{
The relationship between size, book-to-market equity ratio, earnings-price ratio, and return for the Tehran stock Exchange
}

\author{
Mohammad Ali Sadeghi Lafmejani*
}

Department of Management and Accounting, South Branch, Islamic Azad University, Tehran Iran

\begin{tabular}{l}
\hline C H R O N I C L E \\
\hline Article history: \\
Received December 5, 2015 \\
Received in revised format \\
February 162016 \\
Accepted June 302016 \\
Available online \\
June 302016 \\
\hline Keywords: \\
Tehran Stock Exchange \\
Value \\
Growth \\
Market sensitivity \\
Liquidity \\
Firm size
\end{tabular}
\begin{abstract}
A B S T R A C T
This paper presents an empirical investigation to determine whether or there is any difference between the returns of two value and growth portfolios, sorted by price-to-earnings $(\mathrm{P} / \mathrm{E})$ and price-to-book value $(\mathrm{P} / \mathrm{BV})$, in terms of the ratios of market sensitivity to index $(\beta)$, firm size and market liquidity in listed firms in Tehran Stock Exchange (TSE) over the period 20012008. The selected firms were collected from those with existing two-consecutive positive $\mathrm{P} / \mathrm{E}$ and $\mathrm{P} / \mathrm{BV}$ ratios and by excluding financial and holding firms. There were five independent variables for the proposed study of this paper including $\mathrm{P} / \mathrm{E}, \mathrm{P} / \mathrm{B}$, market size, market sensitivity beta $(\beta)$ and market liquidity. In each year, we first sort firms in non-decreasing order and setup four set of portfolios with equal firms. Therefore, the first portfolio with the lowest $\mathrm{P} / \mathrm{E}$ ratio is called value portfolio and the last one with the highest $\mathrm{P} / \mathrm{E}$ ratio is called growth portfolio. This process was repeated based on $\mathrm{P} / \mathrm{BV}$ ratio to determine value and growth portfolios, accordingly. The study investigated the characteristics of two portfolios based on firm size, $\beta$ and liquidity. The study has implemented t-student and Levin's test to examine different hypotheses and the results have indicated mix effects of market sensitivity, firm size and market liquidity on returns of the firms in various periods.
\end{abstract}

\section{Introduction}

During the past few years, there have been several studies indicating that value stocks could outperform growth stocks (Bondt, \& Thaler, 1985). Basu (1977) is believed to be the first who reported that low price-to-earnings $(\mathrm{P} / \mathrm{E})$ US stocks called value stocks may preserve higher average returns than firms with high P/E stocks called growth stocks. Chan et al. (1991) also reported a similar trend in value stocks using Japanese data. Such findings have been corroborated by Fama and French (1992, 1993, 1996), Lakonishok et al. (1994), and Chan and Lakonishok (2004) in the US and Europe, Australia, and the Far East stock markets, respectively. Several investigations have implemented US data and the price-to-book value $(\mathrm{P} / \mathrm{BV})$ ratio to find out the value premium, which is the difference in returns between value and growth stocks. The use of the P/BV ratio was primarily motivated by the work of Fama and French (1992, 1995), which bring ambiguity on the validity of the Capital Asset Pricing 
Model by indicating that the P/BV ratio and size were the key explanatory variables of US cross sectional average stock returns.

Athanassakos (2009) shed light on the value premium using Canadian data from 1985-2005 and a look for process involving both $\mathrm{P} / \mathrm{E}$ and $\mathrm{P} / \mathrm{BV}$ ratios. The research provided a strong value premium over the sample period, which persisted in both bull and bear markets, as well as in recessions and recoveries. Barbee et al. (2008) investigated the relationships of different market multiples with subsequent annual returns for portfolios of liquid U.S. stocks. Huang et al. (2007) decomposed P/E ratios into a fundamental and residual components, which could not be described by the firm or economic fundamentals and reported that portfolios based on residual $\mathrm{P} / \mathrm{E}$ ratios could preserve performance reversal only in overbid glamour stocks. Lam (2002) investigated the relationship between size, bookto-market equity ratio, earnings-price ratio, and return for the Hong Kong stock market. They reported that we reported that $\beta$ was unable to describe the average monthly returns on stocks continuously listed in Hong Kong Stock Exchange. However, three of the variables, size, book-to-market equity, and $E / P$ ratios, appeared to be able to capture the cross-sectional variation in average monthly returns over the period.

\section{The proposed study}

This paper presents an empirical investigation to determine whether or there is any difference between the returns of two value and growth portfolios, sorted by price-to-earnings $(\mathrm{P} / \mathrm{E})$ and price-to-book value $(\mathrm{P} / \mathrm{BV})$, in terms of the ratios of market sensitivity to index $(\beta)$, firm size and market liquidity in listed firms in Tehran Stock Exchange (TSE) over the period 2001-2008. The selected firms were collected from those with existing two-consecutive positive $\mathrm{P} / \mathrm{E}$ and $\mathrm{P} / \mathrm{BV}$ ratios and by excluding financial and holding firms.

There were five independent variables for the proposed study of this paper including $\mathrm{P} / \mathrm{E}, \mathrm{P} / \mathrm{B}$, market size, market sensitivity beta $(\beta)$ and market liquidity. In each year, we first sort firms in non-decreasing order and setup four set of portfolios with equal firms. Therefore, the first portfolio with the lowest P/E ratio is called value portfolio and the last one with the highest $\mathrm{P} / \mathrm{E}$ ratio is called growth portfolio. This process was repeated based on $\mathrm{P} / \mathrm{BV}$ ratio to determine value and growth portfolios, accordingly. The study investigated the characteristics of two portfolios based on firm size, $\beta$ and liquidity. Table 1 shows the summary of some descriptive information of the data gathered from TSE market.

\section{Table 1}

The summary of some descriptive information

\begin{tabular}{ccccccccc}
\hline Period & N & Mean & $\begin{array}{c}\text { Std. } \\
\text { Deviation }\end{array}$ & Min & Max & th25 & $\begin{array}{c}\text { Percentiles } \\
\text { 50th (Median) }\end{array}$ & th75 \\
\hline $2001-2002$ & 220 & 41.0861 & 107.2839 & -320.29 & 1074.39 & -4.7325 & 14.265 & 63.8875 \\
$2002-2003$ & 228 & 56.4584 & 116.7570 & -102.42 & 658.4 & -6.1250 & 19.235 & 81.8650 \\
$2003-2004$ & 216 & 36.1269 & 84.3584 & -91.09 & 480.17 & -12.3550 & 8.785 & 61.5600 \\
$2004-2005$ & 248 & -8.9243 & 109.6332 & -1618.98 & 210.25 & -28.6475 & -6.48 & 11.7250 \\
$2005-2006$ & 276 & 30.7973 & 111.0195 & -257.58 & 1328.02 & -8.1825 & 6.84 & 34.1150 \\
$2006-2007$ & 260 & 19.8104 & 66.66835 & -107.5 & 386.46 & -16.3725 & 3.37 & 34.7075 \\
$2007-2008$ & 216 & 2.041 & 37.25533 & -76.38 & 187.94 & -20.315 & 0.275 & 19.94 \\
\hline
\end{tabular}

In addition, Table 2 demonstrates the results of Kolmogorov-Smirnov test. As we can observe from the results of Table 2, data were not normally distrusted and we need to use Levene's test for equality of variances to examine different hypotheses of the survey. 
Table 2

The summary of Kolmogorov-Smirnov test

\begin{tabular}{llccccccc}
\hline & & \multicolumn{7}{c}{ Return } \\
\cline { 3 - 8 } Year & $01-02$ & $02-03$ & $03-04$ & $04-05$ & $05-06$ & $06-07$ & $07-08$ \\
\hline $\mathrm{N}$ & & 220 & 228 & 216 & 248 & 276 & 260 & 216 \\
\hline \multirow{2}{*}{ Normal Parameters } & Mean & 41.0861 & 56.4584 & 36.126 & -8.9243 & 30.7973 & 19.810 & 2.041 \\
& Std. Dev. & 107.28 & 116.76 & 84.36 & 109.63 & 111.02 & 66.67 & 37.26 \\
\hline \multirow{2}{*}{ Most Extreme } & Absolute & 0.178 & 0.186 & 0.161 & 0.308 & 0.242 & 0.166 & 0.106 \\
& Positive & 0.178 & 0.186 & 0.161 & 0.23 & 0.242 & 0.166 & 0.106 \\
& Negative & -0.171 & -0.149 & -0.139 & -0.308 & -0.213 & -0.103 & -0.057 \\
\hline Kolmogorov-Smirnov Z & & 2.634 & 2.811 & 2.365 & 4.846 & 4.019 & 2.669 & 1.558 \\
Asymp. Sig. (2-tailed) & & 0 & 0 & 0 & 0 & 0 & 0 & 0.016 \\
\hline
\end{tabular}

\section{The results}

In this section, we present the results of testing different hypotheses of the survey based on t-student and Levene's test for equality of variances. For all hypotheses, $\mathrm{H}_{0}$ indicates that two variances are equal $\left(\sigma_{1}^{2}=\sigma_{2}^{2}\right)$ and $H_{1}$ denotes that the variances of two groups are not equal $\left(\sigma_{1}^{2} \neq \sigma_{2}^{2}\right)$.

\subsection{First hypothesis: Difference between two value and growth portfolios according to P/E ratio}

The first hypothesis of the survey investigates whether there is any difference between the returns of two portfolios of value and growth in terms of $\mathrm{P} / \mathrm{E}$ ratio. Table 3 shows the results of the survey. As we can observe from the results of Table 2, the null hypothesis is rejected for some years and it is accepted for some other years.

Table 3

The summary of the testing the first hypothesis

\begin{tabular}{|c|c|c|c|c|c|c|c|c|c|c|}
\hline \multirow{2}{*}{$\mu_{v}-\mu_{\mathrm{g}}$} & \multirow{2}{*}{ \# of firms } & \multicolumn{3}{|c|}{ Levene's test } & \multirow{2}{*}{$\mathrm{t}$} & \multirow{2}{*}{ df } & \multicolumn{2}{|c|}{$95 \%$ Confidence interval } & \multirow{2}{*}{ sig } & \multirow{2}{*}{ Result } \\
\hline & & $\mathrm{F}$ & sig & Result & & & Lower & Upper & & \\
\hline 2001-2002 & 55 & 0.22 & 0.63 & $\sigma_{1}^{2}=\sigma_{2}^{2}$ & 2.1 & 108 & 3.17 & 107.14 & 0.03 & $\mathrm{H}_{0}$ is rejected \\
\hline $2002-2003$ & 57 & 4.85 & 0.03 & $\sigma_{1}^{2} \neq \sigma_{2}^{2}$ & 2.47 & 91 & 12.51 & 113.63 & 0.01 & $\mathrm{H}_{0}$ is rejected \\
\hline 2003-2004 & 54 & 2.05 & 0.15 & $\sigma_{1}^{2}=\sigma_{2}^{2}$ & 2.28 & 106 & 4.80 & 67.90 & 0.02 & $\mathrm{H}_{0}$ is rejected \\
\hline 2004-2005 & 62 & 1.75 & 0.18 & $\sigma_{1}^{2}=\sigma_{2}^{2}$ & 1.25 & 122 & -19.73 & 87.33 & 0.21 & $\mathrm{H}_{0}$ is accepted \\
\hline $2005-2006$ & 69 & 1.93 & 0.16 & $\sigma_{1}^{2}=\sigma_{2}^{2}$ & -0.42 & 135 & -52.30 & 33.78 & 0.67 & $\mathrm{H}_{0}$ is accepted \\
\hline 2006-2007 & 65 & 1.31 & 0.25 & $\sigma_{1}^{2}=\sigma_{2}^{2}$ & 1.27 & 128 & -6.87 & 31.90 & 0.20 & $\mathrm{H}_{0}$ is accepted \\
\hline $2007-2008$ & 54 & 0.36 & 0.54 & $\sigma_{1}^{2}=\sigma_{2}^{2}$ & 2.09 & 106 & 0.75 & 27.96 & 0.03 & $\mathrm{H}_{0}$ is rejected \\
\hline
\end{tabular}

\subsubsection{Difference between the returns of two value portfolios in terms of $\beta$}

The first sub-hypothesis of the first hypothesis determines whether or not there is any differences between two value portfolios in terms of their $\beta s$ sorted by $\mathrm{P} / \mathrm{E}$ ratio. Table 4 demonstrates the results of the survey. According to our survey, except in one year, most of the times, there were no significant differences between two value portfolios in terms of their betas.

Table 4

The summary of testing the difference between two value portfolios in terms of their betas

\begin{tabular}{|c|c|c|c|c|c|c|c|c|c|c|}
\hline \multirow[t]{2}{*}{$\mu_{v l}-\mu_{\mathrm{vh}}$} & \multirow[t]{2}{*}{$\#$ of firms } & \multicolumn{3}{|c|}{ Levene's test } & \multirow[t]{2}{*}{$\mathrm{t}$} & \multirow[t]{2}{*}{$\mathrm{df}$} & \multicolumn{2}{|c|}{$95 \%$ Confidence interval } & \multirow[t]{2}{*}{ sig } & \multirow[t]{2}{*}{ Result } \\
\hline & & $F$ & sig & Result & & & Lower & Upper & & \\
\hline $2001-2002$ & 13 & 1.34 & 0.25 & $\sigma_{1}^{2}=\sigma_{2}^{2}$ & -0.05 & 24 & -60.08 & 56.95 & 0.95 & $\mathrm{H}_{0}$ is accepted \\
\hline $2002-2003$ & 14 & 8.38 & 0.00 & $\sigma_{1}^{2} \neq \sigma_{2}^{2}$ & -1.51 & 26 & -146.17 & 23.78 & 0.14 & $\mathrm{H}_{0}$ is accepted \\
\hline 2003-2004 & 13 & 0.12 & 0.72 & $\sigma_{1}^{2}=\sigma_{2}^{2}$ & 0.40 & 24 & -44.10 & 65.63 & 0.68 & $\mathrm{H}_{0}$ is accepted \\
\hline 2004-2005 & 15 & 0.58 & 0.45 & $\sigma_{1}^{2}=\sigma_{2}^{2}$ & -0.49 & 28 & -27.84 & 16.95 & 0.62 & $\mathrm{H}_{0}$ is accepted \\
\hline $2005-2006$ & 17 & 1.28 & 0.26 & $\sigma_{1}^{2}=\sigma_{2}^{2}$ & 1.92 & 32 & 3.60 & 56.95 & 0.06 & $\mathrm{H}_{0}$ is rejected \\
\hline $2006-2007$ & 16 & 3.45 & 0.07 & $\sigma_{1}^{2}=\sigma_{2}^{2}$ & -0.63 & 30 & -38.9 & 20.64 & 0.53 & $\mathrm{H}_{0}$ is accepted \\
\hline $2007-2008$ & 13 & 0.08 & 0.77 & $\sigma_{1}^{2}=\sigma_{2}^{2}$ & 1.20 & 24 & -13.58 & 51.64 & 0.24 & $\mathrm{H}_{0}$ is accepted \\
\hline
\end{tabular}




\subsubsection{Difference between two value portfolios in terms of firm size}

The second sub-hypothesis of the first hypothesis tries to find out whether or not there is any differences between two value portfolios in terms of their firm sizes sorted by $\mathrm{P} / \mathrm{E}$ ratio. Table 5 shows the results of the survey. Based on the survey, except in one period, there were no significant differences between two value portfolios in terms of their firm sizes.

Table 5

The summary of testing the difference between two value portfolios in terms of their firm sizes

\begin{tabular}{|c|c|c|c|c|c|c|c|c|c|c|}
\hline \multirow{2}{*}{$\mu_{v l}-\mu_{\mathrm{vh}}$} & \multirow[t]{2}{*}{ \# of firms } & \multicolumn{3}{|c|}{ Levene's test } & \multirow[t]{2}{*}{$\mathrm{t}$} & \multirow[t]{2}{*}{$\mathrm{df}$} & \multicolumn{2}{|c|}{$95 \%$ Confidence interval } & \multirow[t]{2}{*}{ sig } & \multirow[t]{2}{*}{ Result } \\
\hline & & $\mathrm{F}$ & sig & Result & & & Lower & Upper & & \\
\hline 2001-2002 & 13 & 3.36 & 0.07 & $\sigma_{1}^{2}=\sigma_{2}^{2}$ & -1.17 & 24 & -263.80 & 72.10 & 0.25 & $\mathrm{H}_{0}$ is accepted \\
\hline $2002-2003$ & 14 & 0.15 & 0.69 & $\sigma_{1}^{2}=\sigma_{2}^{2}$ & -0.55 & 26 & -207.17 & 118.52 & 0.58 & $\mathrm{H}_{0}$ is accepted \\
\hline 2003-2004 & 13 & 9.71 & 0.00 & $\sigma_{1}^{2} \neq \sigma_{2}^{2}$ & 2.73 & 14.47 & 21.37 & 173.40 & 0.01 & $\mathrm{H}_{0}$ is rejected \\
\hline 2004-2005 & 15 & 1.96 & 0.17 & $\sigma_{1}^{2}=\sigma_{2}^{2}$ & 0.32 & 28 & -23.38 & 32.05 & 0.75 & $\mathrm{H}_{0}$ is accepted \\
\hline $2005-2006$ & 17 & 0.55 & 0.46 & $\sigma_{1}^{2}=\sigma_{2}^{2}$ & 0.63 & 32 & -31.03 & 58.83 & 0.53 & $\mathrm{H}_{0}$ is accepted \\
\hline 2006-2007 & 16 & 0.37 & 0.54 & $\sigma_{1}^{2}=\sigma_{2}^{2}$ & 0.97 & 30 & -17.69 & 50.23 & 0.33 & $\mathrm{H}_{0}$ is accepted \\
\hline $2007-2008$ & 13 & 1.45 & 0.23 & $\sigma_{1}^{2}=\sigma_{2}^{2}$ & -0.69 & 24 & -34.54 & 17.16 & 0.49 & $\mathrm{H}_{0}$ is accepted \\
\hline
\end{tabular}

\subsubsection{Difference between two value portfolios in terms of firm liquidity}

The third sub-hypothesis of the first hypothesis tries to find out whether or not there is any differences between two value portfolios in terms of their firm liquidity sorted by P/E ratio. Table 6 presents the results of the findings. Based on the survey, for all cases, there were no significant differences between two value portfolios in terms of their firm liquidities.

Table 6

The summary of testing the difference between two value portfolios in terms of their firm liquidities

\begin{tabular}{|c|c|c|c|c|c|c|c|c|c|c|}
\hline \multirow{2}{*}{$\mu_{v l}-\mu_{\mathrm{vh}}$} & \multirow[t]{2}{*}{$\#$ of firms } & \multicolumn{3}{|c|}{ Levene's test } & \multirow[t]{2}{*}{$\mathrm{t}$} & \multirow[t]{2}{*}{$\mathrm{df}$} & \multicolumn{2}{|c|}{$95 \%$ Confidence interval } & \multirow[t]{2}{*}{ sig } & \multirow[t]{2}{*}{ Result } \\
\hline & & $\mathrm{F}$ & sig & Result & & & Lower & Upper & & \\
\hline 2001-2002 & 13 & 0.97 & 0.33 & $\sigma_{1}{ }^{2}=\sigma_{2}{ }^{2}$ & -0.45 & 24 & -229.23 & 146.83 & 0.65 & $\mathrm{H}_{0}$ is accepted \\
\hline $2002-2003$ & 14 & 0.11 & 0.73 & $\sigma_{1}^{2}=\sigma_{2}^{2}$ & 0.68 & 26 & -109.23 & 217.53 & 0.50 & $\mathrm{H}_{0}$ is accepted \\
\hline 2003-2004 & 13 & 0.39 & 0.53 & $\sigma_{1}^{2}=\sigma_{2}^{2}$ & 0.30 & 24 & -55.77 & 75 & 0.76 & $\mathrm{H}_{0}$ is accepted \\
\hline 2004-2005 & 15 & 0.08 & 0.77 & $\sigma_{1}^{2}=\sigma_{2}^{2}$ & -0.85 & 28 & -39.36 & 16.09 & 0.39 & $\mathrm{H}_{0}$ is accepted \\
\hline $2005-2006$ & 17 & 3.06 & 0.08 & $\sigma_{1}^{2}=\sigma_{2}^{2}$ & -1.37 & 32 & -84.23 & 17.39 & 0.18 & $\mathrm{H}_{0}$ is accepted \\
\hline $2006-2007$ & 16 & 1.98 & 0.17 & $\sigma_{1}^{2}=\sigma_{2}^{2}$ & -1.26 & 30 & -52.77 & 12.39 & 0.21 & $\mathrm{H}_{0}$ is accepted \\
\hline $2007-2008$ & 13 & 6.28 & 0.01 & $\sigma_{1}^{2}=\sigma_{2}^{2}$ & -0.58 & 17.06 & -47.52 & 26.98 & 0.56 & $\mathrm{H}_{0}$ is accepted \\
\hline
\end{tabular}

\subsubsection{Difference between two growth portfolios in terms of $\beta$}

The fourth sub-hypothesis of the first hypothesis determines whether or not there is any differences between two growth portfolios in terms of their $\beta s$ sorted by $\mathrm{P} / \mathrm{E}$ ratio. Table 7 demonstrates the results of the survey. According to our study, except in one period, most of the times, there were no significant differences between two growth portfolios in terms of their betas.

Table 7

The summary of testing the difference between two growth portfolios in terms of their betas

\begin{tabular}{|c|c|c|c|c|c|c|c|c|c|c|}
\hline \multirow{2}{*}{$\mu_{v l}-\mu_{\mathrm{vh}}$} & \multirow[t]{2}{*}{$\#$ of firms } & \multicolumn{3}{|c|}{ Levene's test } & \multirow[t]{2}{*}{$\mathrm{t}$} & \multirow[t]{2}{*}{$\mathrm{df}$} & \multicolumn{2}{|c|}{$95 \%$ Confidence interval } & \multirow[t]{2}{*}{ sig } & \multirow[t]{2}{*}{ Result } \\
\hline & & $\mathrm{F}$ & sig & Result & & & Lower & Upper & & \\
\hline $2001-2002$ & 13 & 3.73 & 0.06 & $\sigma_{1}^{2}=\sigma_{2}^{2}$ & 0.93 & 24 & -48 & 127.84 & 0.35 & $\mathrm{H}_{0}$ is accepted \\
\hline $2002-2003$ & 14 & 0.60 & 0.44 & $\sigma_{1}^{2}=\sigma_{2}^{2}$ & -1.15 & 26 & -143.49 & 49.34 & 0.25 & $\mathrm{H}_{0}$ is accepted \\
\hline $2003-2004$ & 13 & 15.03 & 0.00 & $\sigma_{1}^{2} \neq \sigma_{2}^{2}$ & 2.83 & 12.70 & 17.07 & 127.92 & 0.01 & $\mathrm{H}_{0}$ is rejected \\
\hline 2004-2005 & 15 & 3.31 & 0.08 & $\sigma_{1}^{2}=\sigma_{2}^{2}$ & -0.82 & 28 & -312.18 & 132.63 & 0.41 & $\mathrm{H}_{0}$ is accepted \\
\hline $2005-2006$ & 17 & 1.73 & 0.19 & $\sigma_{1}^{2}=\sigma_{2}^{2}$ & 0.39 & 32 & -42.85 & 63.45 & 0.96 & $\mathrm{H}_{0}$ is accepted \\
\hline $2006-2007$ & 16 & 0.47 & 0.49 & $\sigma_{1}^{2}=\sigma_{2}^{2}$ & 0.33 & 30 & -49.37 & 68.62 & 0.74 & $\mathrm{H}_{0}$ is accepted \\
\hline $2007-2008$ & 13 & 0.36 & 0.55 & $\sigma_{1}^{2}=\sigma_{2}^{2}$ & 0.07 & 24 & -25.25 & 27.19 & 0.94 & $\mathrm{H}_{0}$ is accepted \\
\hline
\end{tabular}




\subsubsection{Difference between two growth portfolios in terms of $\beta$}

The fifth sub-hypothesis of the first hypothesis determines whether or not there is any differences between two growth portfolios in terms of their $\beta s$ sorted by $\mathrm{P} / \mathrm{E}$ ratio. Table 7 demonstrates the results of the survey. According to our study, which indicate there were some differences between two growth portfolios in terms of their betas.

Table 7

The summary of testing the difference between two growth portfolios in terms of their betas

\begin{tabular}{|c|c|c|c|c|c|c|c|c|c|c|}
\hline \multirow{2}{*}{$\mu_{v l}-\mu_{\mathrm{vh}}$} & \multirow[t]{2}{*}{ \# of firms } & \multicolumn{3}{|c|}{ Levene's test } & \multirow[t]{2}{*}{$\mathrm{t}$} & \multirow[t]{2}{*}{$\mathrm{df}$} & \multicolumn{2}{|c|}{$95 \%$ Confidence interval } & \multirow[t]{2}{*}{ sig } & \multirow[t]{2}{*}{ Result } \\
\hline & & $\mathrm{F}$ & sig & Result & & & Lower & Upper & & \\
\hline 2001-2002 & 13 & 0.22 & 0.64 & $\sigma_{1}{ }^{2}=\sigma_{2}{ }^{2}$ & -1.65 & 24 & -146.31 & 16.07 & 0.11 & $\mathrm{H}_{0}$ is accepted \\
\hline $2002-2003$ & 14 & 0.93 & 0.34 & $\sigma_{1}^{2}=\sigma_{2}^{2}$ & -2.24 & 26 & -137.77 & -6.03 & 0.03 & $\mathrm{H}_{0}$ is rejected \\
\hline 2003-2004 & 13 & 17.05 & 0.00 & $\sigma_{1}^{2} \neq \sigma_{2}^{2}$ & 3.42 & 12.41 & 31.03 & 138.11 & 0.00 & $\mathrm{H}_{0}$ is rejected \\
\hline 2004-2005 & 15 & 3.47 & 0.07 & $\sigma_{1}^{2}=\sigma_{2}^{2}$ & -0.85 & 28 & -316.92 & 130.48 & 0.40 & $\mathrm{H}_{0}$ is accepted \\
\hline $2005-2006$ & 17 & 4.83 & 0.03 & $\sigma_{1}^{2} \neq \sigma_{2}^{2}$ & 1.20 & 16.55 & -72.53 & 265.43 & 0.24 & $\mathrm{H}_{0}$ is accepted \\
\hline $2006-2007$ & 16 & 1.29 & 0.26 & $\sigma_{1}^{2}=\sigma_{2}^{2}$ & 1.83 & 30 & 3.78 & 95.44 & 0.07 & $\mathrm{H}_{0}$ is rejected \\
\hline $2007-2008$ & 13 & 6.05 & 0.02 & $\sigma_{1}^{2} \neq \sigma_{2}^{2}$ & -3.03 & 20.66 & -57.22 & -10.68 & 0.00 & $\mathrm{H}_{0}$ is rejected \\
\hline
\end{tabular}

\subsubsection{Difference between the returns of two growth portfolios in terms of liquidity}

The six sub-hypothesis of the first hypothesis determines whether or not there is any differences between two growth portfolios in terms of their $\beta s$ sorted by $\mathrm{P} / \mathrm{E}$ ratio. Table 8 shows the results of the survey. According to our study, there is no difference between two value and growth portfolios in terms of their betas.

\section{Table 8}

The summary of testing the difference between two growth portfolios in terms of their betas

\begin{tabular}{|c|c|c|c|c|c|c|c|c|c|c|}
\hline \multirow{2}{*}{$\mu_{v l}-\mu_{\mathrm{vh}}$} & \multirow{2}{*}{ \# of firms } & \multicolumn{3}{|c|}{ Levene's test } & \multirow[t]{2}{*}{$\mathrm{t}$} & \multirow[t]{2}{*}{ df } & \multicolumn{2}{|c|}{$95 \%$ Confidence interval } & \multirow[t]{2}{*}{ sig } & \multirow{2}{*}{ Result } \\
\hline & & $\mathrm{F}$ & sig & Result & & & Lower & Upper & & \\
\hline 2001-2002 & 13 & 0.53 & 0.47 & $\sigma_{1}^{2}=\sigma_{2}^{2}$ & 0.46 & 24 & -66.91 & 105.36 & 0.64 & $\mathrm{H}_{0}$ is accepted \\
\hline $2002-2003$ & 14 & 0.00 & 0.99 & $\sigma_{1}^{2}=\sigma_{2}^{2}$ & 0.58 & 26 & -63.51 & 114.11 & 0.56 & $\mathrm{H}_{0}$ is accepted \\
\hline 2003-2004 & 13 & 0.00 & 0.93 & $\sigma_{1}^{2}=\sigma_{2}^{2}$ & -1.36 & 24 & -69.79 & 14.18 & 0.18 & $\mathrm{H}_{0}$ is accepted \\
\hline 2004-2005 & 15 & 3.51 & 0.07 & $\sigma_{1}^{2}=\sigma_{2}^{2}$ & 0.75 & 28 & -141.77 & 305.97 & 0.45 & $\mathrm{H}_{0}$ is accepted \\
\hline $2005-2006$ & 17 & 3.30 & 0.07 & $\sigma_{1}^{2}=\sigma_{2}^{2}$ & -0.90 & 32 & -235.50 & 90 & 0.37 & $\mathrm{H}_{0}$ is accepted \\
\hline 2006-2007 & 16 & 10.40 & 0.00 & $\sigma_{1}^{2} \neq \sigma_{2}^{2}$ & 1.32 & 15.92 & -23.89 & 103.01 & 0.20 & $\mathrm{H}_{0}$ is accepted \\
\hline $2007-2008$ & 13 & 0.07 & 0.79 & $\sigma_{1}^{2}=\sigma_{2}^{2}$ & -0.02 & 24 & -28.02 & 27.06 & 0.98 & $\mathrm{H}_{0}$ is accepted \\
\hline
\end{tabular}

\subsection{Second hypothesis: Difference between two value and growth portfolios according to P/B ratio}

The second hypothesis of the survey examines whether there is any difference between the returns of two portfolios of value and growth in terms of P/BV ratio. Table 9 shows the results of the survey and the results are somehow mixed. Therefore, we cannot make a precise judgement.

Table 9

The summary of the testing the second main hypothesis

\begin{tabular}{|c|c|c|c|c|c|c|c|c|c|c|}
\hline \multirow{2}{*}{$\mu_{v}-\mu_{\mathrm{g}}$} & \multirow{2}{*}{ \# of firms } & \multicolumn{3}{|c|}{ Levene's test } & \multirow{2}{*}{$\mathrm{t}$} & \multirow{2}{*}{$\mathrm{df}$} & \multicolumn{2}{|c|}{$95 \%$ Confidence interval } & \multirow{2}{*}{ sig } & \multirow{2}{*}{ Result } \\
\hline & & $\mathrm{F}$ & sig & Result & & & Lower & Upper & & \\
\hline 2001-2002 & 55 & 0.70 & 0.44 & $\sigma_{1}^{2}=\sigma_{2}^{2}$ & -0.60 & 108 & -65.24 & 34.57 & 0.54 & $\mathrm{H}_{0}$ is accepted \\
\hline $2002-2003$ & 57 & 3.47 & 0.06 & $\sigma_{1}^{2}=\sigma_{2}^{2}$ & 1.44 & 112 & -12.17 & 77.45 & 0.15 & $\mathrm{H}_{0}$ is accepted \\
\hline 2003-2004 & 54 & 11.74 & 0.00 & $\sigma_{1}^{2} \neq \sigma_{2}^{2}$ & 3.44 & 70.19 & 23.22 & 87.32 & 0.00 & $\mathrm{H}_{0}$ is rejected \\
\hline 2004-2005 & 62 & 1.45 & 0.22 & $\sigma_{1}^{2}=\sigma_{2}^{2}$ & -1.33 & 122 & -89.06 & 17.39 & 0.18 & $\mathrm{H}_{0}$ is accepted \\
\hline 2005-2006 & 69 & 1.83 & 0.17 & $\sigma_{1}^{2}=\sigma_{2}^{2}$ & -0.01 & 131.28 & -22.76 & 22.34 & 0.98 & $\mathrm{H}_{0}$ is accepted \\
\hline $2006-2007$ & 65 & 7.46 & 0.00 & $\sigma_{1}^{2} \neq \sigma_{2}^{2}$ & 3.34 & 96.39 & 17.13 & 67.16 & 0.00 & $\mathrm{H}_{0}$ is rejected \\
\hline $2007-2008$ & 54 & 2.29 & 0.13 & $\sigma_{1}^{2}=\sigma_{2}^{2}$ & 1.63 & 106 & -2.33 & 23.90 & 0.10 & $\mathrm{H}_{0}$ is accepted \\
\hline
\end{tabular}




\subsubsection{Difference between the returns of two value portfolios in terms of $\beta$}

The first sub-hypothesis of the second hypothesis determines whether or not there is any differences between two value portfolios in terms of their $\beta s$ sorted by $\mathrm{P} / \mathrm{BV}$ ratio. Table 10 demonstrates the results of the survey. According to our survey, there were no significant differences between two value portfolios in terms of their betas.

Table 10

The summary of testing the difference between two value portfolios in terms of their betas

\begin{tabular}{|c|c|c|c|c|c|c|c|c|c|c|}
\hline \multirow{2}{*}{$\mu_{v l}-\mu_{\mathrm{vh}}$} & \multirow[t]{2}{*}{ \# of firms } & \multicolumn{3}{|c|}{ Levene's test } & \multirow[t]{2}{*}{$\mathrm{t}$} & \multirow[t]{2}{*}{$\mathrm{df}$} & \multicolumn{2}{|c|}{$95 \%$ Confidence interval } & \multirow[t]{2}{*}{ sig } & \multirow[t]{2}{*}{ Result } \\
\hline & & $\mathrm{F}$ & sig & Result & & & Lower & Upper & & \\
\hline 2001-2002 & 3.02 & 13 & 3.02 & $\sigma_{1}{ }^{2}=\sigma_{2}{ }^{2}$ & 0.19 & 24 & -31.23 & 37.69 & 0.89 & $\mathrm{H}_{0}$ is accepted \\
\hline $2002-2003$ & 5.90 & 14 & 5.90 & $\sigma_{1}{ }^{2} \neq \sigma_{2}^{2}$ & -1.05 & 18.80 & -124.69 & 40.09 & 0.30 & $\mathrm{H}_{0}$ is accepted \\
\hline 2003-2004 & 0.02 & 13 & 0.02 & $\sigma_{1}^{2}=\sigma_{2}^{2}$ & 0.56 & 24 & -72.02 & 126.88 & 0.57 & $\mathrm{H}_{0}$ is accepted \\
\hline $2004-2005$ & 0.14 & 15 & 0.14 & $\sigma_{1}^{2}=\sigma_{2}^{2}$ & 0.07 & 28 & -20.70 & 22.30 & 0.94 & $\mathrm{H}_{0}$ is accepted \\
\hline $2005-2006$ & 1.54 & 17 & 1.54 & $\sigma_{1}^{2}=\sigma_{2}^{2}$ & -0.33 & 32 & -39.74 & 27.28 & 0.70 & $\mathrm{H}_{0}$ is accepted \\
\hline 2006-2007 & 0.09 & 16 & 0.09 & $\sigma_{1}^{2}=\sigma_{2}^{2}$ & 0.22 & 30 & -50.67 & 63.08 & 0.82 & $\mathrm{H}_{0}$ is accepted \\
\hline $2007-2008$ & 0.23 & 13 & 0.23 & $\sigma_{1}^{2}=\sigma_{2}^{2}$ & -0.19 & 24 & -37.28 & 30.94 & 0.85 & $\mathrm{H}_{0}$ is accepted \\
\hline
\end{tabular}

\subsubsection{Difference between two value portfolios in terms of firm size}

The second sub-hypothesis of the second hypothesis tries to find out whether or not there is any differences between two value portfolios in terms of their firm sizes sorted by P/BV ratio. Table 11 shows the results of the survey. Based on the survey, there were no significant differences between two value portfolios in terms of their firm sizes.

\section{Table 11}

The summary of testing the difference between two value portfolios in terms of their firm sizes

\begin{tabular}{|c|c|c|c|c|c|c|c|c|c|c|}
\hline \multirow{2}{*}{$\mu_{v l}-\mu_{\mathrm{vh}}$} & \multirow{2}{*}{ \# of firms } & \multicolumn{3}{|c|}{ Levene's test } & \multirow[t]{2}{*}{$\mathrm{t}$} & \multirow[t]{2}{*}{$\mathrm{df}$} & \multicolumn{2}{|c|}{ 95\% Confidence interval } & \multirow{2}{*}{ sig } & \multirow{2}{*}{ Result } \\
\hline & & $\mathrm{F}$ & sig & Result & & & Lower & Upper & & \\
\hline $2001-2002$ & 13 & 8.34 & 0.00 & $\sigma_{1}^{2} \neq \sigma_{2}^{2}$ & -1.53 & 12.17 & -331.25 & 57.20 & 0.13 & $\mathrm{H}_{0}$ is accepted \\
\hline $2002-2003$ & 14 & 2.44 & 0.13 & $\sigma_{1}^{2}=\sigma_{2}^{2}$ & -1.86 & 26 &.-181.21 & -8.21 & 0.07 & $\mathrm{H}_{0}$ is accepted \\
\hline 2003-2004 & 13 & 0.46 & 0.50 & $\sigma_{1}^{2}=\sigma_{2}^{2}$ & 0.41 & 24 & -35.75 & 53.72 & 0.68 & $\mathrm{H}_{0}$ is accepted \\
\hline $2004-2005$ & 15 & 3.58 & 0.06 & $\sigma_{1}^{2} \neq \sigma_{2}^{2}$ & -0.82 & 28 & -312.75 & 132.63 & 0.41 & $\mathrm{H}_{0}$ is accepted \\
\hline $2005-2006$ & 17 & 1.14 & 0.29 & $\sigma_{1}^{2}=\sigma_{2}^{2}$ & 0.24 & 32 & -44.47 & 56.63 & 0.80 & $\mathrm{H}_{0}$ is accepted \\
\hline $2006-2007$ & 16 & 0.14 & 0.70 & $\sigma_{1}^{2}=\sigma_{2}^{2}$ & 0.81 & 30 & -40.18 & 93.90 & 0.42 & $\mathrm{H}_{0}$ is accepted \\
\hline $2007-2008$ & 13 & 8.73 & 0.00 & $\sigma_{1}^{2} \neq \sigma_{2}^{2}$ & 1.14 & 15.56 & -13.89 & 46.37 & 0.27 & $\mathrm{H}_{0}$ is accepted \\
\hline
\end{tabular}

\subsubsection{Difference between two value portfolios in terms of firm liquidity}

The third sub-hypothesis of the second hypothesis tries to find out whether or not there is any differences between two value portfolios in terms of their firm liquidity sorted by P/BV ratio. Table 12 presents the results of the findings. Based on the survey, for all cases, there were no significant differences between two value portfolios in terms of their firm liquidities.

Table 12

The summary of testing the difference between two value portfolios in terms of their firm liquidities

\begin{tabular}{|c|c|c|c|c|c|c|c|c|c|c|}
\hline \multirow{2}{*}{$\mu_{v l}-\mu_{\mathrm{vh}}$} & \multirow[t]{2}{*}{ \# of firms } & \multicolumn{3}{|c|}{ Levene's test } & \multirow[t]{2}{*}{$\mathrm{t}$} & \multirow[t]{2}{*}{ df } & \multicolumn{2}{|c|}{$95 \%$ Confidence interval } & \multirow[t]{2}{*}{ sig } & \multirow[t]{2}{*}{ Result } \\
\hline & & $\mathrm{F}$ & sig & Result & & & Lower & Upper & & \\
\hline 2001-2002 & 13 & 0.97 & 0.33 & $\sigma_{1}^{2}=\sigma_{2}^{2}$ & -0.45 & 24 & -229.23 & 146.83 & 0.65 & $\mathrm{H}_{0}$ is accepted \\
\hline $2002-2003$ & 14 & 0.11 & 0.73 & $\sigma_{1}^{2}=\sigma_{2}^{2}$ & 0.68 & 26 & -109.23 & 217.53 & 0.50 & $\mathrm{H}_{0}$ is accepted \\
\hline 2003-2004 & 13 & 0.39 & 0.53 & $\sigma_{1}^{2}=\sigma_{2}^{2}$ & 0.30 & 24 & -55.77 & 75 & 0.76 & $\mathrm{H}_{0}$ is accepted \\
\hline 2004-2005 & 15 & 0.08 & 0.77 & $\sigma_{1}^{2}=\sigma_{2}^{2}$ & -0.85 & 28 & -39.36 & 16.09 & 0.39 & $\mathrm{H}_{0}$ is accepted \\
\hline $2005-2006$ & 17 & 3.06 & 0.08 & $\sigma_{1}^{2}=\sigma_{2}^{2}$ & -1.37 & 32 & -84.23 & 17.39 & 0.18 & $\mathrm{H}_{0}$ is accepted \\
\hline 2006-2007 & 16 & 1.98 & 0.17 & $\sigma_{1}^{2}=\sigma_{2}^{2}$ & -1.26 & 30 & -52.77 & 12.39 & 0.21 & $\mathrm{H}_{0}$ is accepted \\
\hline $2007-2008$ & 13 & 6.28 & 0.01 & $\sigma_{1}^{2}=\sigma_{2}^{2}$ & -0.58 & 17.06 & -47.52 & 26.98 & 0.56 & $\mathrm{H}_{0}$ is accepted \\
\hline
\end{tabular}


The fourth sub-hypothesis of the second hypothesis determines whether or not there is any differences between two growth portfolios in terms of their $\beta s$ sorted by $\mathrm{P} / \mathrm{BV}$ ratio. Table 13 demonstrates the results of the survey. According to our study, except in two periods, most of the times, there were no significant differences between two growth portfolios in terms of their betas.

Table 13

The summary of testing the difference between two growth portfolios in terms of their betas

\begin{tabular}{|c|c|c|c|c|c|c|c|c|c|c|}
\hline \multirow[t]{2}{*}{$\mu_{v l}-\mu_{\mathrm{vh}}$} & \multirow[t]{2}{*}{ \# of firms } & \multicolumn{3}{|c|}{ Levene's test } & \multirow[t]{2}{*}{$\mathrm{t}$} & \multirow[t]{2}{*}{$\mathrm{df}$} & \multicolumn{2}{|c|}{$95 \%$ Confidence interval } & \multirow[t]{2}{*}{ sig } & \multirow[t]{2}{*}{ Result } \\
\hline & & $\mathrm{F}$ & sig & Result & & & Lower & Upper & & \\
\hline $2001-2002$ & 13 & 0.47 & 0.49 & $\sigma_{1}^{2}=\sigma_{2}^{2}$ & 1.32 & 24 & -22.45 & 103.31 & 0.19 & $\mathrm{H}_{0}$ is accepted \\
\hline $2002-2003$ & 14 & 1 & 0.32 & $\sigma_{1}^{2}=\sigma_{2}^{2}$ & -1.09 & 26 & -130.50 & 39.97 & 0.28 & $\mathrm{H}_{0}$ is accepted \\
\hline 2003-2004 & 13 & 3.87 & 0.06 & $\sigma_{1}^{2}=\sigma_{2}^{2}$ & 2.93 & 24 & 14.96 & 86.14 & 0.00 & $\mathrm{H}_{0}$ is rejected \\
\hline 2004-2005 & 15 & 11.14 & 0.00 & $\sigma_{1}^{2} \neq \sigma_{2}^{2}$ & -0.47 & 17.86 & -36.07 & 22.74 & 0.64 & $\mathrm{H}_{0}$ is accepted \\
\hline $2005-2006$ & 17 & 6.51 & 0.01 & $\sigma_{1}^{2} \neq \sigma_{2}^{2}$ & -2.46 & 20.46 & -130.75 & -11.02 & 0.02 & $\mathrm{H}_{0}$ is rejected \\
\hline 2006-2007 & 16 & 1.07 & 0.30 & $\sigma_{1}^{2}=\sigma_{2}^{2}$ & -0.75 & 30 & -49.02 & 22.48 & 0.45 & $\mathrm{H}_{0}$ is accepted \\
\hline $2007-2008$ & 13 & 1.56 & 0.22 & $\sigma_{1}^{2}=\sigma_{2}^{2}$ & 1.55 & 24 & -5.63 & 39.66 & 0.13 & $\mathrm{H}_{0}$ is accepted \\
\hline
\end{tabular}

\subsubsection{Difference between the returns of two growth portfolios in terms of size}

The fifth sub-hypothesis of the second hypothesis determines whether or not there is any differences between two growth portfolios in terms of their sizes sorted by P/BV ratio. Table 14 demonstrates the results of the survey. According to our study, except one period, there were no differences between two growth portfolios in terms of their sizes.

\section{Table 14}

The summary of testing the difference between two value portfolios in terms of their sizes

\begin{tabular}{|c|c|c|c|c|c|c|c|c|c|c|}
\hline \multirow{2}{*}{$\mu_{v l}-\mu_{\mathrm{vh}}$} & \multirow[t]{2}{*}{ \# of firms } & \multicolumn{3}{|c|}{ Levene's test } & \multirow[t]{2}{*}{$\mathrm{t}$} & \multirow[t]{2}{*}{$\mathrm{df}$} & \multicolumn{2}{|c|}{$95 \%$ Confidence interval } & \multirow[t]{2}{*}{ sig } & \multirow[t]{2}{*}{ Result } \\
\hline & & $\mathrm{F}$ & sig & Result & & & Lower & Upper & & \\
\hline 2001-2002 & 13 & 0.05 & 0.81 & $\sigma_{1}^{2}=\sigma_{2}^{2}$ & -0.24 & 24 & -60.28 & 47.43 & 0.8 & $\mathrm{H}_{0}$ is accepted \\
\hline $2002-2003$ & 14 & 0.25 & 0.62 & $\sigma_{1}^{2}=\sigma_{2}^{2}$ & -1.45 & 26 & -117.20 & 20.04 & 0.15 & $\mathrm{H}_{0}$ is accepted \\
\hline 2003-2004 & 13 & 1.33 & 0.25 & $\sigma_{1}^{2}=\sigma_{2}^{2}$ & 0.01 & 24 & -29.09 & 29.6 & 0.98 & $\mathrm{H}_{0}$ is accepted \\
\hline 2004-2005 & 15 & 1.99 & 0.16 & $\sigma_{1}^{2}=\sigma_{2}^{2}$ & 3.40 & 28 & 16.61 & 66.62 & 0.00 & $\mathrm{H}_{0}$ is rejected \\
\hline $2005-2006$ & 17 & 0.27 & 0.60 & $\sigma_{1}^{2}=\sigma_{2}^{2}$ & -0.24 & 32 & -43.54 & 34.17 & 0.8 & $\mathrm{H}_{0}$ is accepted \\
\hline $2006-2007$ & 16 & 0.05 & 0.81 & $\sigma_{1}^{2}=\sigma_{2}^{2}$ & 0.87 & 30 & -12.79 & 32.15 & 0.38 & $\mathrm{H}_{0}$ is accepted \\
\hline $2007-2008$ & 13 & 0.12 & 0.72 & $\sigma_{1}^{2}=\sigma_{2}^{2}$ & -0.10 & 24 & -23.59 & 21.37 & 0.72 & $\mathrm{H}_{0}$ is accepted \\
\hline
\end{tabular}

\subsubsection{Difference between the returns of two growth portfolios in terms of liquidity}

The six sub-hypothesis of the second hypothesis determines whether or not there is any differences between two growth portfolios in terms of their liquidities sorted by $\mathrm{P} / \mathrm{BV}$ ratio. Table 15 shows the results of the survey. According to our study, except two periods, there were no differences between two growth portfolios in terms of their betas.

Table 15

The summary of testing the difference between two growth portfolios in terms of their liquidity

\begin{tabular}{|c|c|c|c|c|c|c|c|c|c|c|}
\hline \multirow{2}{*}{$\mu_{v l}-\mu_{\mathrm{vh}}$} & \multirow[t]{2}{*}{ \# of firms } & \multicolumn{3}{|c|}{ Levene's test } & \multirow[t]{2}{*}{$\mathrm{t}$} & \multirow[t]{2}{*}{$\mathrm{df}$} & \multicolumn{2}{|c|}{$95 \%$ Confidence interval } & \multirow[t]{2}{*}{ sig } & \multirow[t]{2}{*}{ Result } \\
\hline & & $\mathrm{F}$ & sig & Result & & & Lower & Upper & & \\
\hline $2001-2002$ & 13 & 1.01 & 0.32 & $\sigma_{1}^{2}=\sigma_{2}^{2}$ & -0.13 & 24 & -80.08 & 70.43 & 0.89 & $\mathrm{H}_{0}$ is accepted \\
\hline $2002-2003$ & 14 & 7.78 & 0.01 & $\sigma_{1}^{2} \neq \sigma_{2}^{2}$ & 2.20 & 20.46 & 4.60 & 168.09 & 0.03 & $\mathrm{H}_{0}$ is rejected \\
\hline 2003-2004 & 13 & 0.00 & 0.95 & $\sigma_{1}^{2}=\sigma_{2}^{2}$ & 0.30 & 24 & -37.08 & 50.11 & 0.76 & $\mathrm{H}_{0}$ is accepted \\
\hline 2004-2005 & 15 & 0.83 & 0.36 & $\sigma_{1}^{2}=\sigma_{2}^{2}$ & -1.67 & 28 & -53.91 & 5.46 & 0.10 & $\mathrm{H}_{0}$ is accepted \\
\hline $2005-2006$ & 17 & 10.93 & 0.002 & $\sigma_{1}^{2} \neq \sigma_{2}^{2}$ & 2.86 & 18.61 & 20.67 & 132.95 & 0.01 & $\mathrm{H}_{0}$ is rejected \\
\hline $2006-2007$ & 16 & 6.23 & 0.01 & $\sigma_{1}^{2} \neq \sigma_{2}^{2}$ & 0.08 & 18.98 & -29.79 & 32.16 & 0.93 & $\mathrm{H}_{0}$ is accepted \\
\hline $2007-2008$ & 13 & 0.38 & 0.54 & $\sigma_{1}^{2}=\sigma_{2}^{2}$ & -1.05 & 24 & -34.44 & 11.20 & 0.30 & $\mathrm{H}_{0}$ is accepted \\
\hline
\end{tabular}




\section{Conclusion}

This paper has presented an empirical investigation to determine whether there is any difference between the returns of two value and growth portfolios, sorted by $\mathrm{P} / \mathrm{E}$ and $\mathrm{P} / \mathrm{BV}$, in terms of the ratios of market sensitivity to index $(\beta)$, firm size and market liquidity in listed firms in Tehran Stock Exchange (TSE) over the period 2001-2008. The study has implemented t-student and Levin's test to examine different hypotheses and the results have indicated mix effects of market sensitivity, firm size and market liquidity in various periods. The results of this survey are somehow in contrast with other findings, which indicated the superiority of value stock against growth stock. In other words, the results of our survey did not find any evidence to claim that the value stocks listed on TSE would outperform growth ones. Moreover, while there were no differences between the variances of two growth and value portfolios in terms of liquidity, the effects of $\beta$ and market size were somehow mixed.

\section{Acknowledgement}

The authors would like to thank the anonymous referees for constructive comments on earlier version of this paper.

\section{References}

Athanassakos, G. (2009). Value versus growth stock returns and the value premium: the Canadian experience 1985-2005. Canadian Journal of Administrative Sciences, 26(2), 109.

Basu, S. (1977). Investment performance of common stocks in relation to their price-earnings ratios: A test of the efficient market hypothesis. The journal of Finance, 32(3), 663-682.

Barbee, W. C., Jeong, J. G., \& Mukherji, S. (2008). Relations between portfolio returns and market multiples. Global Finance Journal, 19(1), 1-10.

Bondt, W. F., \& Thaler, R. (1985). Does the stock market overreact?. The Journal of finance, 40(3), 793-805.

Chan, L. K., \& Lakonishok, J. (2004). Value and growth investing: Review and update. Financial Analysts Journal, 60(1), 71-86.

Fama, E.F., \& French, K.R. (1992). The cross section of expected stock returns. Journal of Finance, 47(2), 427-465.

Fama, E.F., \& French, K.R. (1993). Common risk factors in the returns on stocks and bonds. Journal of Financial Economics, 33(1), 3-56.

Fama, E.F., \& French, K.R. (1995). Size and book-to-market factors in earnings and returns. Journal of Finance, 50(1), 131-155.

Fama, E. F., \& French, K. R. (1996). Multifactor explanations of asset pricing anomalies. The journal of finance, 51(1), 55-84.

Lakonishok, J., Shleifer, A., \& Vishny, R. W. (1994). Contrarian investment, extrapolation, and risk. The journal of finance, 49(5), 1541-1578.

Lam, K. S. (2002). The relationship between size, book-to-market equity ratio, earnings-price ratio, and return for the Hong Kong stock market. Global Finance Journal, 13(2), 163-179.

Huang, Y., Tsai, C. H., \& Chen, C. R. (2007). Expected P/E, residual P/E, and stock return reversal: time-varying fundamentals or investor overreaction?. International Journal of Business and Economics, 6(1), 11. 